\title{
Cold Plasma Treatment on Mustard Green Seeds and its Effect on Growth, Isothiocyanates, Antioxidant Activity and Anticancer Activity of Microgreens
}

\author{
Worachot Saengha $^{1}$, Thipphiya Karirat ${ }^{1}$, Benjaporn Buranrat ${ }^{2}$, Khanit Matra ${ }^{3}$, Sirirat Deeseenthum ${ }^{1}$, Teeraporn \\ Katisart $^{4}$ and Vijitra Luang-In ${ }^{*}$ \\ ${ }^{1}$ Natural Antioxidant Innovation Research Unit, Department of Biotechnology, Faculty of Technology, Mahasarakham \\ University, Maha Sarakham 44150, Thailand \\ ${ }^{2}$ Faculty of Medicine, Mahasarakham University, Maha Sarakham 44000, Thailand \\ ${ }^{3}$ Department of Electrical Engineering, Faculty of Engineering, Srinakharinwirot University, Nakhon Nayok 26120, Thailand \\ ${ }^{4}$ Department of Biology, Faculty of Science, Mahasarakham University, Maha Sarakham 44150, Thailand \\ *For correspondence: vijitra.1@msu.ac.th; vijitra.luangin@gmail.com \\ Received 11 November 2020; Accepted 09 December 2020; Published 25 January 2021
}

\begin{abstract}
The aims of this work were to study growth, isothiocyanate (ITC), bioactive content, antioxidant activity and anticancer activity of mustard green (MG) microgreens grown from seeds treated with cold plasma at 21 and $23 \mathrm{kV}$ for 5 min. Microgreens from plasma-treated seeds at $23 \mathrm{kV}$ showed almost 2-fold increased ITC content $(1.57 \pm 0.05 \mathrm{mmol} / 100 \mathrm{~g} \mathrm{DW})$ compared to MG from seeds without plasma (control), showed the highest total phenolic content (TPC) $(6.76 \pm 0.14 \mathrm{mg}$ GAE/g DW) and total flavonoid content (TFC) $(0.16 \pm 0.01 \mathrm{mg}$ RE/g DW). However, MG plasma-treated seeds at $21 \mathrm{kV}$ showed the highest antioxidant activity from 2,2-Diphenyl-1-picrylhydrazyl (DPPH) assay (3.51 $\pm 0.38 \mathrm{mg}$ TE/g DW). Allyl isothiocyanate and 3-butenyl isothiocyanate were the dominant ITCs in MG. The highest cytotoxicities using 3-(4,5Dimethylthiazol-2-yl)-2,5-diphenyltetrazolium bromide (MTT) assay against MCF-7 (IC 50 of $32.44 \pm 1.64 \mu \mathrm{g} / \mathrm{mL}$ ) and HepG2 $\left(\mathrm{IC}_{50}\right.$ of $\left.28.58 \pm 1.04 \mu \mathrm{g} / \mathrm{mL}\right)$ after $72 \mathrm{~h}$ exposure were found in MG from plasma-treated seeds at $23 \mathrm{kV}$ and MG from control seeds, respectively. However, MG from plasma-treated seeds at $21 \mathrm{kV}$ exhibited the highest antiproliferative effect against MCF-7 ( $\mathrm{IC}_{50}$ of $23.23 \pm 0.23 \mu \mathrm{g} / \mathrm{mL}$ ) and HepG2 $\left(\mathrm{IC}_{50}\right.$ of $20.44 \pm 0.56 \mu \mathrm{g} / \mathrm{mL}$ ) for 14 days and also the most potent antimigratory effect. MG from cold plasma inhibited MMP-9 protein expression in both cancers indicating antimigratory property. MG from cold plasma also significantly reduced $M M P-9$ mRNA expression in both cancers when compared to the control and untreated cells. In conclusion, cold plasma treatment on seeds seemed to be an innovative tool to enhance ITC, TPC, TFC and anticancer properties of MG microgreens for better health implications. (C) 2021 Friends Science Publishers
\end{abstract}

Keywords: Allyl isothiocyanate; Chemoprevention; Cold plasma; Microgreen; Mustard green

\section{Introduction}

Microgreens are plants with a few cotyledons from vegetable seeds after planting for approximately 7-14 days and have gained momentum among healthy consumers in the past ten years (Kyriacou et al. 2016). Microgreens contain several phytochemicals and thus they are known for risks reduction of various diseases (Shahidi 2006), such as ischemic heart disease, stroke and cancers (Kennedy and Wightman 2011; Khanam et al. 2012; Alrifai et al. 2019).

In Thailand, approximately half of the cancer burden is due to five types of cancers: lung, liver, breast, colorectal, and gall bladder cancers (Bray et al. 2018). Several cancers are preventable by a nationwide campaign to encourage a regular consumption of local Thai vegetables, especially those in Cruciferae family. Brassica juncea (L.) Czern and Coss or mustard green (MG) is a local Cruciferous vegetable commonly grown in Northeast Thailand. Glucosinolates are secondary metabolites ubiquitous in vegetables of Cruciferae family (Fahey et al. 2001). Once come into contact with myrosinase enzyme (Van Eylen $e t$ al. 2006), glucosinolates are converted into isothiocyanates (ITCs), thiocyanates, nitriles and epithionitriles (Halkier and Gershenzon 2006). ITCs are bioactive compounds exhibiting antibacterial, antimould and anticancer effects (Singh and Singh 2012). These are able to induce Phase II enzyme through an expression of NF-E2-related factor-2 (Thimmulappa et al. 2002; Zhang and Hannink 2003), inhibit histone deacetylases (Wang et al. 2008), inhibit cell cycle and Bcl-2 protein expression (Xiao et al. 2006; Zhang

To cite this paper: Saengha W, T Karirat, B Buranrat, K Matra, S Deeseenthum, T Katisart, V Luang-In (2021). Cold plasma treatment on mustard green seeds and its effect on growth, isothiocyanates, antioxidant activity and anticancer activity of microgreens. Intl J Agric Biol 25:667-676 
and Tang 2007; Geng et al. 2011), stimulate caspases and activates the transcription factor 3 (Wu et al. 2005; Park et al. 2007). The MG contains sinigrin and allyl isothiocyanate (AITC) (Ishida et al. 2014) and also other phytochemicals including carotenoids and phenolic compounds (Frazie et al. 2017) exhibiting antioxidant capacity (Ishida et al. 2014). To date, only reports on MG mature plants have existed and the knowledge on the type and quantity of ITCs and bioactivities of MG microgreens is still scarce.

At present, non-thermal plasma (NTP) or cold plasma technology application in food and agriculture has gained momentum. The benefits of NTP lie with its non-thermal, economical, flexible and environmentally friendly nature (Pankaj et al. 2017). During the food processing stage, applications of NTP for improving functionality of food were recorded (Muhammad et al. 2018). The changes caused by NTP are primarily related to oxidative degradation and double bonds cleavage in plant-derived organic compounds. To date, the effects have been reported mostly on increases in polyphenol, vitamin $\mathrm{C}$ and antioxidant activity in a timedependent manner (Muhammad et al. 2018) and also the extraction efficiency of polyphenols has been improved. However, the effect of NTP on food functionality of seeds or plants prior to food processing step has not yet been extensively examined. Very few studies have shown that NTP was used to improve seed surface, germination percentage and growth rate of certain plants (Dobrin et al. 2015; Butscher et al. 2016; Burnett et al. 2017). Therefore, this work aimed to test the hypothesis that cold plasma treatment on MG seeds was able to increase seed germination, ITC content, bioactive compounds and anticancer activity of MG microgreens when compared to those grown from the control seeds without plasma treatment.

\section{Materials and Methods}

\section{MG microgreen cultivation and cold plasma treatment}

Cold plasma treatment on MG seeds was carried out at Faculty of Engineering Srinakharinwirot University, Nakhon Nayok Province. The experimental set up design is shown in Fig. 1. MG seeds of Lanna cultivar (Sorndang brand) were purchased from Punthawee mall shop (https://www.pwcmallonline.com), Lot. no. 304333. MG seeds (100 seeds/replicate/treatment) in triplicate were treated with cold plasma at the supplied voltages of 21 or $23 \mathrm{kV}$ for $5 \mathrm{~min}$. Both supplied voltages were chosen for the test since our preliminary work showed the optimal voltage at $21 \mathrm{kV}$ to increase ITC content and bioactivity of Thai rat-tailed radish microgreens from cold plasmatreated seeds (unpublished data). MG seeds were germinated on vermiculite in a tray at $25^{\circ} \mathrm{C}(12 \mathrm{~h} \mathrm{light} / 12$ dark cycle, light intensity controlled at $\left.42 \mu \mathrm{mol} / \mathrm{s} / \mathrm{m}^{2}\right)$ and were sprayed with $20 \mathrm{~mL}$ of deionized water for 7 days' till harvested. Percent seed germination, stem length and dry weight of MG microgreens were measured after gentle cut 1

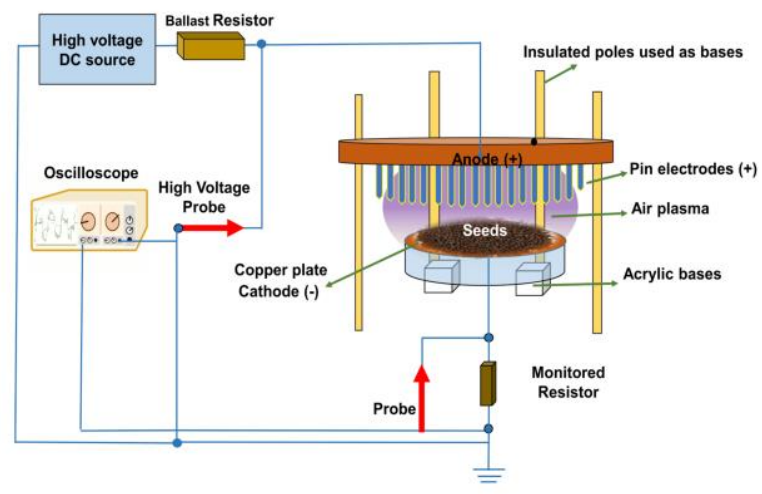

Fig. 1: Schematic drawing of cold plasma device setup A DC high voltage power supply (Matsusada, AU-30P10) was connected to the $16 \varnothing$ $\mathrm{cm}$ circular PCB BreadBoard anode, attached to $0.2 \varnothing \mathrm{mm}$ multi-pin electrodes, through a $6 \mathrm{M} \Omega$ ballast resistor. The $0.5 \mathrm{~cm}$ space was placed between two pin electrodes on the anode plate. A $12 \times 12 \mathrm{~cm}^{2}$ copper cathode plate as a tray for placing the plant seeds, was grounded. Between the multi-pin anodes and cathode tray with a space gap of $1.4 \mathrm{~cm}$, air plasma was generated at room temperature when the high voltage was applied across both electrodes at 19 and $23 \mathrm{kV}$ with the average supplied current of $0.53 \mathrm{~mA}$

$\mathrm{cm}$ above the vermiculite surface. Fresh microgreens were harvested for further analyses.

\section{Extraction and determination of ITCs}

ITCs of 7-day old MG microgreens were extracted as previously reported (Luang-In et al. 2018). Briefly, MG microgreens were freeze-dried and then dried samples (250 $\mathrm{mg}$ ) were added with $0.1 \mathrm{M}$ citrate-phosphate buffer $\mathrm{pH} 7.0$ $(4 \mathrm{~mL})$ and incubated in a shaking incubator at $250 \mathrm{rpm}$ (LSI-1005R, Lab Tech, Korea) for $1 \mathrm{~h}$ at $37^{\circ} \mathrm{C}$. The extract was mixed with dichloromethane (DCM) (RCI Labscan, Thailand) in the ratio of 1:1 and was incubated for $30 \mathrm{~min}$ at $37^{\circ} \mathrm{C}$ with shaking at $250 \mathrm{rpm}$. The samples were centrifuged at $10,000 \times \mathrm{g}$ for $15 \mathrm{~min}$ and thereafter DCM phase (bottom layer) was obtained and mixed with $0.5 \mathrm{~g}$ of $\mathrm{MgSO}_{4}$ for water removal. Extracted samples were centrifuged as previously and the supernatants were obtained for total ITC content determination (Amron and Konsue 2018). The supernatants were diluted in methanol in the ratio of 1:4 and the diluted sample $(10 \mu \mathrm{L})$ was added to the 96-well plate and mixed with $90 \mu \mathrm{L}$ of methanol. An aliquot $(90 \mu \mathrm{L})$ of $0.1 M$ phosphate buffer $\mathrm{pH} 8.0$ and $10 \mu \mathrm{L}$ of $0.08 M$ benzene 1,2 dithiol (Sigma, St. Louis, MO, USA) were added and incubated at $60^{\circ} \mathrm{C}$ for $2 \mathrm{~h}$. The A365 nm measurement was recorded using M965+ microplate reader (Metertech, Taipei, Taiwan). Benzyl isothiocyanate (BITC) was used to calibrate ITC standard curve. ITCs were identified as previously done (Luang-In et al. 2014). Gas chromatograph-mass spectrometry (GC-MS) (Agilent HP$5 \mathrm{MS})$ with $5 \%$ phenylmethylsiloxane column $(30 \mathrm{~m} \times$ $0.25 \mathrm{~mm}, 0.25 \mu \mathrm{m}$ ) was used with helium as a carrier gas. The temperature of oven was started at $50^{\circ} \mathrm{C}$ for $5 \mathrm{~min}$ and ramped up to $150^{\circ} \mathrm{C}$ and $250^{\circ} \mathrm{C}\left(4^{\circ} \mathrm{C} / \mathrm{min}\right)$. The amount of injection was $1 \mu \mathrm{L}$, the flow rate was $1 \mathrm{~mL} / \mathrm{min}$, the average 
velocity was $36 \mathrm{~cm} / \mathrm{min}$, the pressure was $7.56 \mathrm{kPa}$ and the overall runtime was $40 \mathrm{~min}$. ITCs were identified using the mass spectral library in GC-MS and standard reference database. AITC and 3-butenyl ITC fingerprint fragment ions were 99, 72 and $55(\mathrm{~m} / \mathrm{z})$ and 113, 72 and $55(\mathrm{~m} / \mathrm{z})$, and113, 72 and $55\left(\mathrm{M}^{+}\right)$, respectively at the retention times of 7.25 and $9.78 \mathrm{~min}$, respectively.

\section{Microgreen extract preparation}

Freeze-dried MG microgreens $(100 \mathrm{mg}$ ) were added to 5 $\mathrm{mL}$ of $80 \%$ methanol, homogenized, incubated with shaking at $250 \mathrm{rpm}$ at $37^{\circ} \mathrm{C}$ for $24 \mathrm{~h}$. The samples were centrifuged at $10,000 \times \mathrm{g}$ for $15 \mathrm{~min}$, and filtered. Supernatants were used for antioxidant activity and bioactive content assays.

\section{Scavenging of DPPH free radical}

The $0.2 \mathrm{mM}$ 2,2-diphenyl-1-picrylhydrazyl (DPPH) radical solution (Sigma, St. Louis, MO, USA) $(180 \mu \mathrm{L})$ was combined with the MG microgreen extract $(20 \mu \mathrm{L})$ and incubated for $30 \mathrm{~min}$ in the dark as in the previous report (Zhang et al. 2016) with a slight modification. Sample absorption was estimated at $515 \mathrm{~nm}$ and the Trolox equivalent (TE) (Sigma, St. Louis, MO, USA) was used.

\section{Ferric reducing antioxidant power (FRAP) assay}

The FRAP reagent was prepared in $300 \mathrm{~m} M$ acetate buffer $\mathrm{pH}$ 3.6, $10 \mathrm{~m} M$ 2,4,6-Tris(2-pyridyl)-s-triazine solution in $40 \mathrm{mM} \mathrm{HCl}$ and $20 \mathrm{~m} M$ iron(III) chloride solution in a 1:1:10 (v/v) ratio (Wei et al. 2011). Subsequently, the FRAP reagent $(180 \mu \mathrm{L})$ was applied to the $\mathrm{MG}$ microgreen extract solution $(20 \mu \mathrm{L})$, mixed well and incubated for $30 \mathrm{~min}$ in the dark. The sample absorbance was measured at $593 \mathrm{~nm}$ and the iron (II) sulfate standard (Sigma, St. Louis, MO, USA) was used.

\section{Total phenolic content (TPC) and total flavonoid content (TFC)}

A Folin-Ciocalteu colorimetric approach was used to evaluate the TPC (Radošević et al. 2017). The MG microgreen extract $(20 \mu \mathrm{L})$ was combined with the reagent Folin-Ciocalteu $(100 \mu \mathrm{L})$ and left for $1 \mathrm{~min}$. The solution of $7.5 \%(\mathrm{w} / \mathrm{v})$ sodium bicarbonate $(80 \mu \mathrm{L})$ was added to the reaction mixture and incubated for $30 \mathrm{~min}$ at room temperature. After that, the measurement at $765 \mathrm{~nm}$ was recorded and the gallic acid equivalent (GAE) (Sigma, St. Louis, MO, USA) was used.

TFC was done according to the previous approach (Tian et al. 2016) with some modifications. Deionized water $(60 \mu \mathrm{L}), 5 \% \mathrm{NaNO}_{3}(10 \mu \mathrm{L}), 10 \% \mathrm{AlCl}_{3} \cdot 6 \mathrm{H}_{2} \mathrm{O}(10 \mu \mathrm{L})$ and MG microgreen extract $(20 \mu \mathrm{L})$ were combined and stood for $1 \mathrm{~min}$. Afterwards, $1 M \mathrm{NaOH}(100 \mu \mathrm{L})$ was added, mixed and incubated for $30 \mathrm{~min}$ prior to measurement at $500 \mathrm{~nm}$ and rutin equivalent (RE) (Sigma, St. Louis, MO, USA) was used.

\section{Cancer cell cultures}

The human breast adenocarcinoma (MCF-7 ATCC $₫$ HTB22TM) and human hepatocellular carcinoma (HepG2 ATCC $®$ HB-8065TM) were received from the American Type Culture Collections (ATCC, Manassas, VA, USA). MCF-7 and HepG2 cells were cultured with $10 \%$ fetal bovine serum (FBS) (Invitrogen, Carlsbad, CA, USA), 100 $\mathrm{U} / \mathrm{mL}$ penicillin (Invitrogen, Carlsbad, CA, USA) and 100 $\mu \mathrm{g} / \mathrm{mL}$ streptomycin (Invitrogen, Carlsbad, CA, USA) in Dulbecco's modified Eagle medium (DMEM) (Invitrogen, Carlsbad, CA, USA). Cells were cultured under $5 \% \mathrm{CO}_{2}$ at $37^{\circ} \mathrm{C}$. When $80 \%$ confluence was reached, DMEM media was refreshed every 2-3 days. Cultured cell lines were washed with phosphate-buffered saline (PBS), $\mathrm{pH} 7.2$, and trypsinized with $0.25 \%$ Trypsin-EDTA (Invitrogen, Carlsbad, CA, USA). Cancer cells were placed in a fresh DMEM medium before further tests.

\section{Microgreen extraction for cell cultures}

MG extraction for cell lines was performed accordingly (Pocasap et al. 2013). Fresh MG microgreens (50 g) were ground in $0.1 \mathrm{M}$ citrate phosphate buffer $(50 \mathrm{~mL}), \mathrm{pH} 7.0$ and mixed at $250 \mathrm{rpm}$ for $2 \mathrm{~h}$ at $37^{\circ} \mathrm{C}$. DCM was then added in the mixed samples in the ratio of 1:1 for ITC extraction for $30 \mathrm{~min}$. The samples were centrifuged at 10,000 $\mathrm{g}$ for 15 min, filtered, evaporated and freeze-dried. Dried samples were mixed with $1 \%$ dimethyl sulfoxide (DMSO) (Fisher Scientific, Loughborough, UK) and the MG microgreen extract solution was used in the next step.

\section{Cytotoxicity assay}

MCF-7 or HepG2 cells $\left(5 \times 10^{3}\right.$ cells $\left./ \mathrm{mL}\right)$ were cultured in 96 -well plates under $5 \% \mathrm{CO}_{2}$ for $24 \mathrm{~h}$ at $37^{\circ} \mathrm{C}$. The $\mathrm{MG}$ microgreen extract $(0-250 \mu \mathrm{g} / \mathrm{mL})$ was exposed to cancer cells for 24, 48 and $72 \mathrm{~h}$. Thereafter, 3-(4,5-dimethylthiazol2-yl)-2,5-diphenyltetrazolium bromide (MTT) $(0.5 \mathrm{mg} / \mathrm{mL})$ was added to wells and incubated for $4 \mathrm{~h}$ and removed before DMSO $(200 \mu \mathrm{L})$ was added. The appearance of purple color corresponded to alive cells.

The absorbance (A) at $590 \mathrm{~nm}$ was measured. Emax (maximum cytotoxicity (\%)) and half maximal inhibitory concentration $\left(\mathrm{IC}_{50}\right)$ values were calculated for the cytotoxicity of microgreen MG extracts against cancer cells.

$$
\text { Emax }=\frac{(\text { Acontrol }- \text { Asample })}{(\text { Acontrol })} \times 100^{\circ}
$$

\section{Clonogenic assay}

The colony forming test was used to determine the influence of MG microgreen extracts on cancer cell proliferation as previously done (Buranrat et al. 2017). The viable cancer cells (800 cells/well) were seeded in 6well plates for $24 \mathrm{~h}$ prior to exposure to microgreen 
extracts $(0,6.25,12.5,25,50$ and $100 \mu \mathrm{g} / \mathrm{mL})$ for $24 \mathrm{~h}$. Cells were then washed with PBS and replenished into a new DMEM for 14-day cultivation. The DMEM medium has subsequently been discarded and cells were washed, fixed and stained with $0.5 \%$ crystal violet for $1 \mathrm{~h}$. After washing cells, the colonies were captured using a digital camera (Nikon D50).

\section{Wound healing assay}

Cell migration was measured with the previously mentioned wound healing assay (Buranrat et al. 2016). MCF-7 or HepG2 $\left(2 \times 10^{5}\right.$ cells/well) were seeded into 24 -well plates overnight. After $90 \%$ confluency was reached, a sterile $0.2 \mathrm{~mL}$ pipette tip was used for scraping the cells to make a straight line. Cells were exposed to $\mathrm{MG}$ microgreen extracts $(25 \mathrm{mg} / \mathrm{mL})$. Pictures at $0,24 \mathrm{~h}$ and $48 \mathrm{~h}$ were recorded.

$$
\text { Relative closure of the scratch }(\%)=\frac{(\text { width of wound at } \mathrm{T} \mathrm{h})}{(\text { width of wound at } 0 \mathrm{~h})} \times 100
$$

Cell migration was observed using phase contrast microscopy (NIB-9000 inverted microscope, Xenon, China).

\section{Gelatin zymography analysis}

The influence of MG microgreen extracts on MMP-2 and MMP-9 protein expression was determined by gelatine zymography (Buranrat et al. 2017). MCF-7 and HepG2 $\left(2 \times 10^{5}\right.$ cells/well $)$ were cultured in the 24 -well plates and were exposed to MG microgreen extracts $(25 \mu \mathrm{g} / \mathrm{mL})$ for 24 h. Cells were collected and extracted for protein content which was later quantified using Bradford reagent (Bio-Rad, UK) with bovine serum albumin as a standard (Bradford 1976). The sample protein $(30 \mu \mathrm{g})$ was studied on $10 \%$ SDS-polyacrylamide gel containing $0.1 \%$ gelatin as substrate under electrophoresis running conditions at $150 \mathrm{~V}$ for $50 \mathrm{~min}$ before staining with $0.25 \%$ Coomassie Brilliant Blue R250. Proteins were analyzed for the relative densities of the bands using ImageJ software (v. 1.46r; U.S. National Institutes of Health) (Rueden et al. 2017).

\section{Reverse transcription-polymerase chain reaction (RT- PCR)}

Gene expressions in cancer cells were analyzed using RTPCR. MCF-7 and HepG2 $\left(2 \times 10^{5}\right.$ cells/well $)$ were cultured into 6-well plates for $24 \mathrm{~h}$ at $37^{\circ} \mathrm{C}$ and then exposed to $\mathrm{MG}$ extracts $(25 \mu \mathrm{g} / \mathrm{mL})$ for $24 \mathrm{~h}$ in fresh media. Cells were collected for RNA isolation using a TRIZol Reagent ${ }^{\circledR}$ (Life Technologies, Carlsbad, CA, USA). The synthesis of cDNAs from RNAs was performed using the iScript ${ }^{\mathrm{TM}}$ cDNA synthesis kit (Bio-Rad, Hercules, CA, USA). After that, PCR reaction using specific primers to genes of interest (Table 1) was conducted. The PCR reaction contained
cDNA products $(1 \mu \mathrm{L})$ and $2 \times$ Master Mix (OnePCR, GeneDirex, Taiwan). PCR thermocycler (Thermo Scientific Hybaid $\mathrm{P} \times 2$ ) was programmed at initial denaturation for 3 min at $94^{\circ} \mathrm{C}$ for 1 cycle, 40 cycles for denaturation at $94^{\circ} \mathrm{C}$ for $45 \mathrm{~s}$, annealing at specific temperatures (Table 1) for 45 $\mathrm{s}$, extension for $1 \mathrm{~min}$ at $72^{\circ} \mathrm{C}$ followed by final extension 1 cycle at $72^{\circ} \mathrm{C}$ for $7 \mathrm{~min}$. Beta-actin was used as an internal standard. The PCR products were analyzed on a $1.5 \%$ agarose gel at $100 \mathrm{~V}$ for $30 \mathrm{~min}$ and were viewed using gel documentation and measured for intensity using ImageJ software.

\section{Cell morphology}

MCF-7 and HepG2 cells (5,000 cells/well) were cultured into 24-well plates for overnight and then were exposed to MG microgreen extracts $(50 \mu \mathrm{g} / \mathrm{mL})$ for $24 \mathrm{~h}$. Cells were captured using an inverted light microscope (NIB-9000, Xenon, China) at $400 \times$ magnification.

\section{DNA fragmentation}

MCF-7 and HepG2 $\left(2 \times 10^{5}\right.$ cells/well) were cultured into 6well plates at $37^{\circ} \mathrm{C}$ under $5 \% \mathrm{CO}_{2}$ for $24 \mathrm{~h}$ and afterwards were exposed to $\mathrm{MG}$ microgreen extracts $(100 \mu \mathrm{g} / \mathrm{mL})$ for $24 \mathrm{~h}$. Cells were collected and the genomic DNA $(1 \mu \mathrm{g} / \mathrm{mL})$ was then extracted using DNA Extraction Kit (Vivantis, Malaysia), analyzed on gel electrophoresis in $1 \%$ agarose gel and viewed using gel documentation (Syngene Gene Flash, UK).

\section{Statistical analysis}

Data collection was done in triplicate and the results were presented as mean \pm standard error (SE). One-way analysis of variance (ANOVA) and Duncan multiple range test by the software S.P.S.S. (demo version) were used for statistical analyses. Statistically significant differences were considered if $P<0.05$.

\section{Results}

\section{Growth of MG microgreens}

The results showed that the MG from cold plasma-treated seeds at $23 \mathrm{kV}$ had the highest germination $(88.66 \pm 3.05 \%)$; however, MG from control seeds (without cold plasma treatment) and those from cold plasma-treated seeds at 21 $\mathrm{kV}$ resulted in similar germination approximately $80 \%$ (Fig. 2A). All three groups of tested MG showed no significant differences in microgreen stem length (Fig. 2B). The highest dry weight of MG came from cold plasma-treated seeds at $23 \mathrm{kV}(7.30 \pm 1.83 \mathrm{mg} /$ microgreen), followed by MG from cold plasma-treated seeds at $21 \mathrm{kV} \quad(7.00 \pm 0.28$ $\mathrm{mg} /$ microgreen) and control $\mathrm{MG} \quad(5.20 \pm 1.13$ $\mathrm{mg} /$ microgreen) (Fig. 2C); however, these measurements were not significant. 
Table 1: Primer sequences for RT-PCR

\begin{tabular}{|c|c|c|c|}
\hline Gene & Product (bp) & Annealing temp $\left({ }^{\circ} \mathrm{C}\right)$ & Forward and reverse primer sequences \\
\hline Beta-actin & 290 & 52 & $5^{\prime}-$ CTGTCTGGCGGCACCACCAT - 3' \\
\hline Bax & 538 & 65 & $\begin{array}{l}5^{\prime}-\text { CAGCTCTGAGCAGATCATGAAGACA - 3' } \\
5^{\prime}-\text { GCCCATCTTCTTCCAGATGGTGAGC }-3^{\prime}\end{array}$ \\
\hline Bcl-2 & 459 & 65 & $\begin{array}{l}5^{\prime}-\text { GGTGCCACCTGTGGTCCACCTG }-3^{\prime} \\
5^{\prime}-\text { CTTCACTTGTGGCCCAGATAGG }-3^{\prime}\end{array}$ \\
\hline Caspase-3 & 419 & 55 & $\begin{array}{l}5^{\prime}-\text { CGGTCTGGTACAGATGTCGAT - 3' } \\
5^{\prime}-\text { TAACCAGGTGCTGTGGAGTATG - } 3\end{array}$ \\
\hline$M M P-9$ & 460 & 61 & $\begin{array}{l}5^{\prime}-\text { CGCTGGGCTTAGATCATTCC- } 3^{\prime} \\
5^{\prime}-\text { TTGTCGGCGATAAGGAA- } 3^{\prime}\end{array}$ \\
\hline
\end{tabular}

A

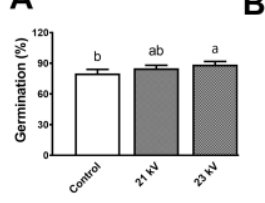

B

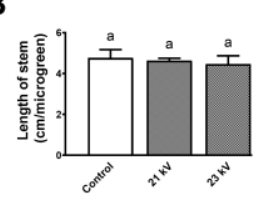

C
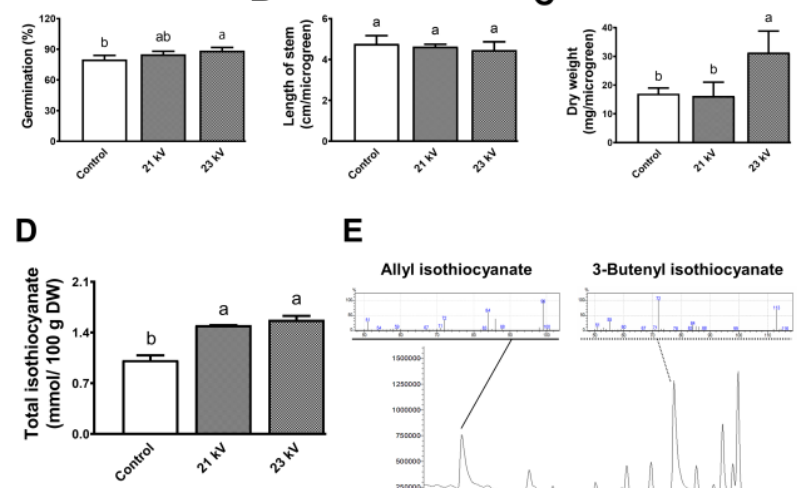

E

$\mathbf{F}$

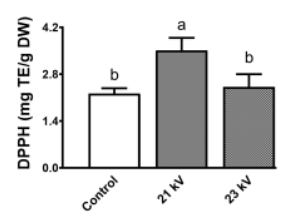

H

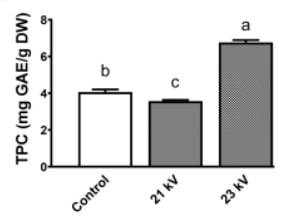

I
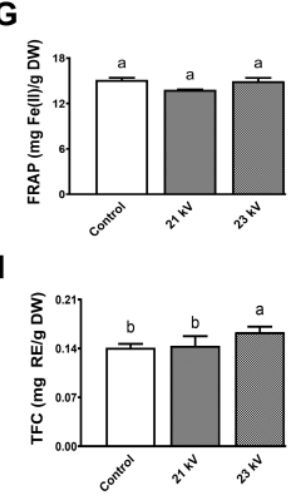

Fig. 2: Growth, bioactive content and antioxidant activities of 7day old MG microgreens: A) Germination (\%), B) Stem length, C) Dry weight, D) Total ITC content, E) GC-MS chromatogram and fingerprint of ITCs, F) DPPH scavenging activity, G) FRAP activity, H) Total phenolic compound (TPC) and I) Total flavonoid compound (TFC). Data represented as mean \pm SE of three independent experiments. Different letters above columns indicate significant differences $(P<0.05)$

Control $=$ MG microgreens from control seeds (no plasma-treated); $21 \mathrm{kV}=$ MG microgreens from plasma-treated seeds at $21 \mathrm{kV} ; 23 \mathrm{kV}=\mathrm{MG}$ microgreens from plasma-treated seeds at $23 \mathrm{kV}$

\section{ITCs in MG microgreens}

The total ITC content increased significantly in MG from cold plasma-treated seeds when compared to those from control seeds (Fig. 2D). The highest total ITC content was found in cold plasma treatment at $23 \mathrm{kV}(1.57 \pm 0.05$

$\mathrm{mmol} / 100 \mathrm{~g} \mathrm{DW})$. This value was not significantly different from that of cold plasma treatment at $21 \mathrm{kV}(1.50 \pm 0.00$ $\mathrm{mmol} / 100 \mathrm{~g} \mathrm{DW}$ ); however, it was almost 2-fold higher than that of the control $(1.02 \pm 0.07 \mathrm{mmol} / 100 \mathrm{~g} \mathrm{DW})$ (Fig. 2D). This suggested that cold plasma treatment at $23 \mathrm{kV}$ on MG seeds was optimal for increasing total ITC content in MG microgreens. Two types of ITCs; AITC and 3-butenyl ITC at $7.25 \mathrm{~min}$ and $9.78 \mathrm{~min}$, respectively were detected in MG samples in three groups using GC-MS (Fig. 2E).

\section{Antioxidant activity and bioactive compounds in MG microgreens}

The highest DPPH antioxidant activity of MG microgreens was found from cold plasma-treated seeds at $21 \mathrm{kV}(3.51 \pm$ $0.38 \mathrm{mg} \mathrm{TE} / \mathrm{g} \mathrm{DW}$ ) which was significantly different from those of the control and $23 \mathrm{kV}$ treatment (Fig. 2F). However, no statistical difference in FRAP activity was found amongst three groups of microgreens (Fig. 2G). The TPC results were significantly different $(P<0.05)$ among all treatments (Fig. $2 \mathrm{H}$ ). Cold plasma treatment at $23 \mathrm{kV}$ on seeds led to the highest TPC $(6.76 \pm 0.14 \mathrm{mg} \mathrm{GAE} / \mathrm{g} \mathrm{DW})$ which was significantly higher than that of the control and cold plasma treatment at $21 \mathrm{kV}$ (Fig. $2 \mathrm{H}$ ). Likewise, the highest TFC $(0.16 \pm 0.01 \mathrm{mg}$ RE/g DW $)$ was from cold plasma treatment at $23 \mathrm{kV}$ and was significantly different from those of the control and cold plasma treatment at 21 kV (Fig. 2I).

\section{Cytotoxicity and antiproliferation of MG microgreens}

Cytotoxicity of MG microgreen extracts $(0-250 \mu \mathrm{g} / \mathrm{mL})$ against the MCF-7 and HepG2 after 24, 48, and $72 \mathrm{~h}$ incubation was determined using MTT assay (Fig. 3). The results showed that the cytotoxicity was time- and dosedependent. MG microgreen extracts from cold plasmatreated seeds at $23 \mathrm{kV}$ exhibited the highest cytotoxicity against MCF-7 after $72 \mathrm{~h}$ exposure with $\mathrm{IC}_{50}$ of $32.44 \pm 1.64$ $\mu \mathrm{g} / \mathrm{mL}$ ) (Fig. 3A). However, MG microgreen extracts from control seeds exhibited the highest cytotoxicity against HepG2 after $72 \mathrm{~h}$ exposure with $\mathrm{IC}_{50}$ of $28.58 \pm 1.04$ $\mu \mathrm{g} / \mathrm{mL}$ ) (Fig. 3B).

The anti-colony formation was performed to measure the effects of MG microgreen extracts $(0-100 \mu \mathrm{g} / \mathrm{mL})$ on long-term cancer cell viability and replicative potential. 
A
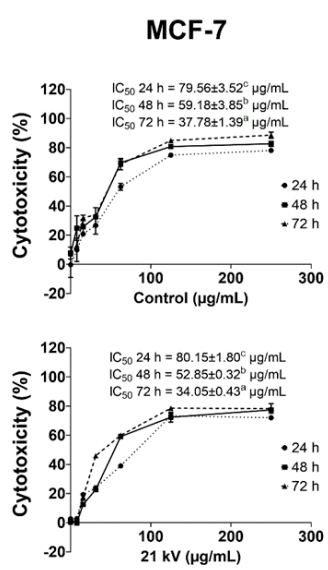

B
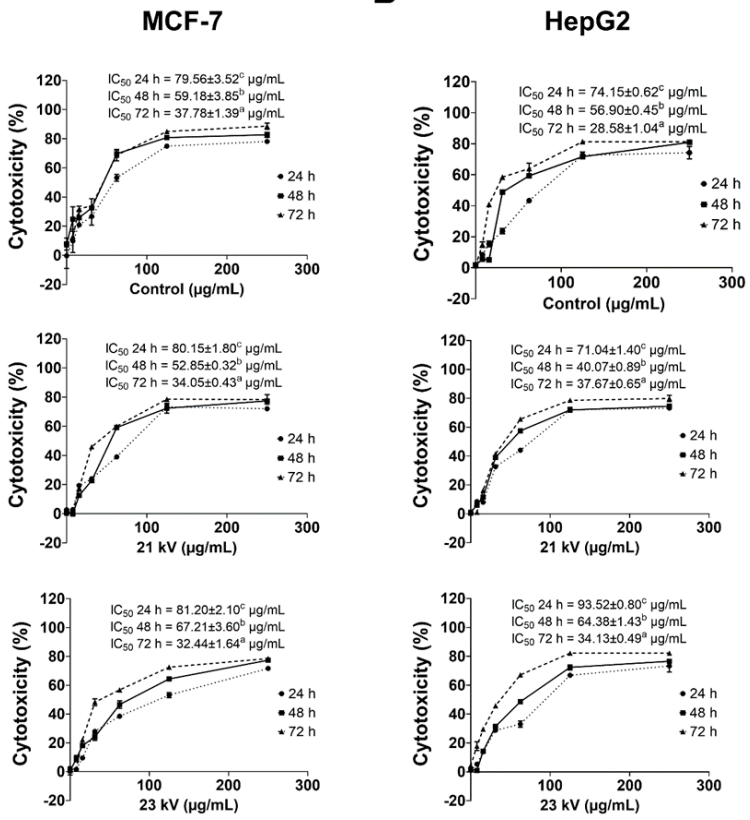

A

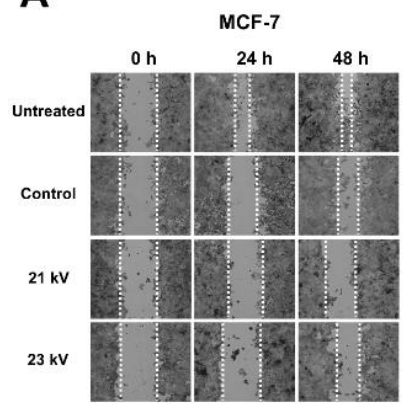

C

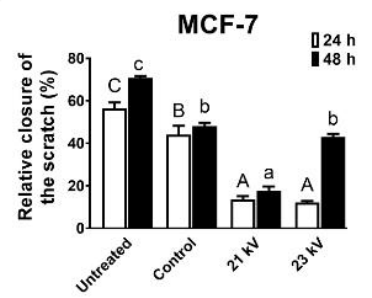

B

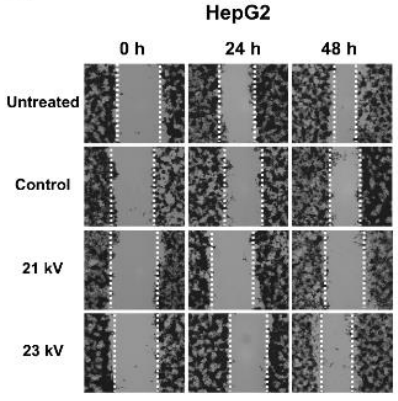

D

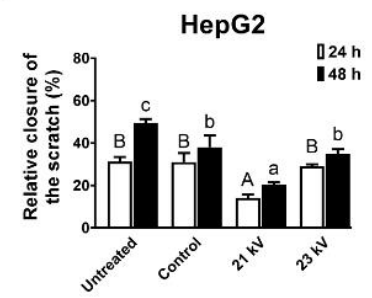

Fig. 3: Cytotoxicity of MG microgreen extracts on cancer cells: A) MCF-7 and B) HepG2

Control = MG microgreens from control seeds (no plasma-treated); $21 \mathrm{kV}=\mathrm{MG}$ microgreens from plasma-treated seeds at $21 \mathrm{kV} ; 23 \mathrm{kV}=\mathrm{MG}$ microgreens from plasma-treated seeds at $23 \mathrm{kV}$

A
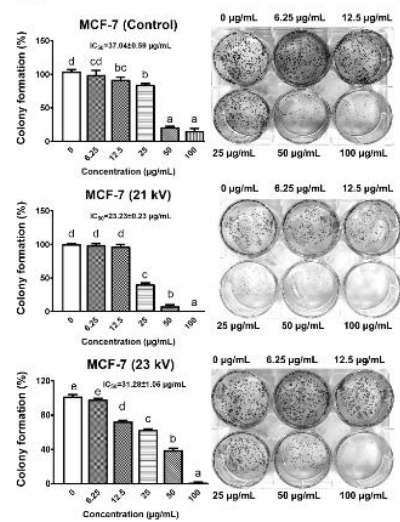

B
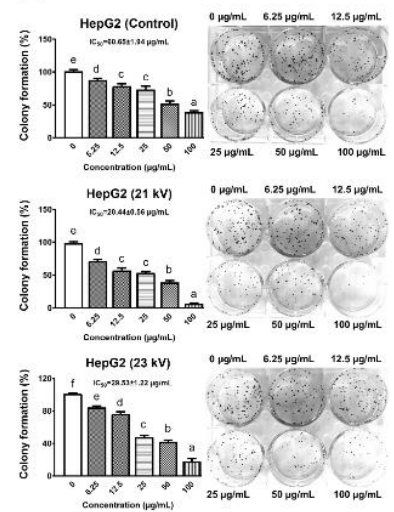

Fig. 4: Anticolony formation: A) MCF-7 and B) HepG2. Data represented as mean $\pm \mathrm{SE}$ of three independent experiments. Different letters above columns indicate significant differences $(P$ $<0.05)$

Control $=$ MG microgreens from control seeds (no plasma-treated); $21 \mathrm{kV}=\mathrm{MG}$ microgreens from plasma-treated seeds at $21 \mathrm{kV} ; 23 \mathrm{kV}=\mathrm{MG}$ microgreens from plasma-treated seeds at $23 \mathrm{kV}$

The results showed that the anti-colony formation of $\mathrm{MG}$ microgreen extracts was dose-dependent in both MCF-7 (Fig. 4A) and HepG2 (Fig. 4B). MG microgreen extracts from cold plasma-treated seeds at $21 \mathrm{kV}$ exerted the most potent antiproliferative effect on $\mathrm{MCF}-7\left(\mathrm{IC}_{50}=23.23 \pm\right.$ $0.23 \mu \mathrm{g} / \mathrm{mL}$ ) (Fig. 4A) and HepG2 cells $\left(\mathrm{IC}_{50}=20.44 \pm\right.$ $0.56 \mu \mathrm{g} / \mathrm{mL}$ ) (Fig. 4B).

Fig. 5: Wound healing assay: A) MCF-7, B) HepG2, C Relative closure of the scratch (\%) of MCF-7 and D Relative closure of the scratch $(\%)$ of HepG2. Different letters above columns indicate significant differences $(P<0.05)$. Uppercase letters for $24 \mathrm{~h}$ and lowercase letters for $48 \mathrm{~h}$. Untreated = Cancer cells without any treatment; Control = MG microgreens from control seeds (no plasma-treated); $21 \mathrm{kV}=\mathrm{MG}$ microgreens from plasma-treated seeds at $21 \mathrm{kV} ; 23 \mathrm{kV}=\mathrm{MG}$ microgreens from plasma-treated seeds at $23 \mathrm{kV}$

\section{Antimigratory effect of MG microgreens}

Antimigratory effect of MG microgreen extracts was tested using wound healing assay. The results clearly demonstrated that MG microgreen extracts $(25 \mu \mathrm{g} / \mathrm{mL})$ from cold plasmatreated seeds at $21 \mathrm{kV}$ inhibited both MCF-7 (Fig. 5A) and HepG2 (Fig. 5B) cell migration after 24 and 48 h. The antimigratory effect from cold plasma-treated seeds at 21 $\mathrm{kV}$ was more pronounced than those from cold plasmatreated seeds at $23 \mathrm{kV}$, control seeds and untreated cells.

Next, gelatinase zymography was carried out to assess the protein expression of invasion-linked matrix metalloproteinase 2 (MMP 2) and matrix metalloproteinase 9 (MMP 9) relating to cancer migration. The results showed that MG microgreen extracts $(25 \mu \mathrm{g} / \mathrm{mL})$ from cold plasmatreated seeds at $21 \mathrm{kV}$ significantly inhibited both MMP 2 and MPP 9 protein expressions in both MCF-7 (Fig. 6A) and HepG2 (Fig. 6B) cells after $48 \mathrm{~h}$ exposure to $25 \mu \mathrm{g} / \mathrm{mL}$ of microgreen extract significantly more than those from cold plasma-treated seeds at $23 \mathrm{kV}$, control seeds and untreated cells.

\section{Gene expressions in cancer cell death}

Gene expressions related to apoptotic pathway in cancer cells were investigated using RT-PCR technique. All MG microgreen extracts increased Bax gene expressions in both 
A

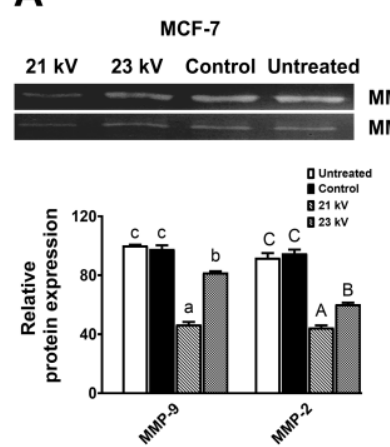

C

MCF-7
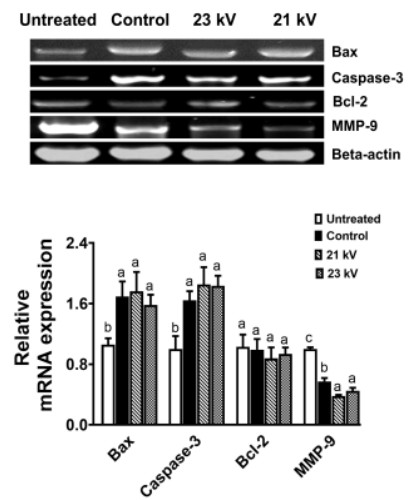

B
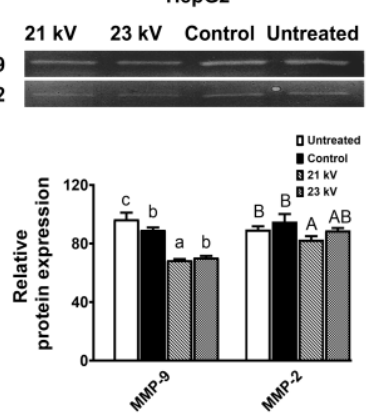

D
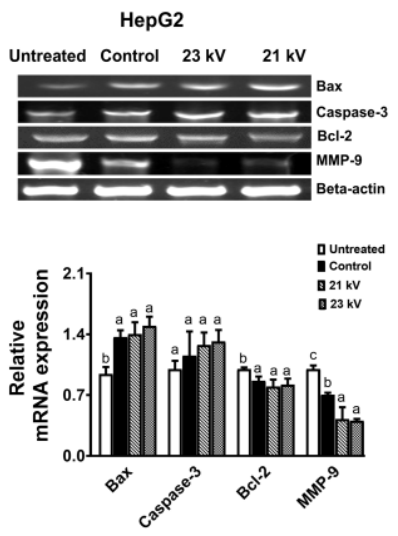

A

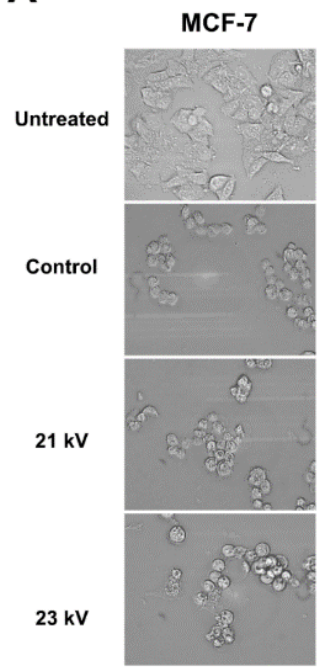

C

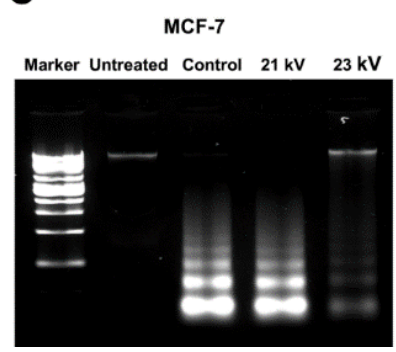

B

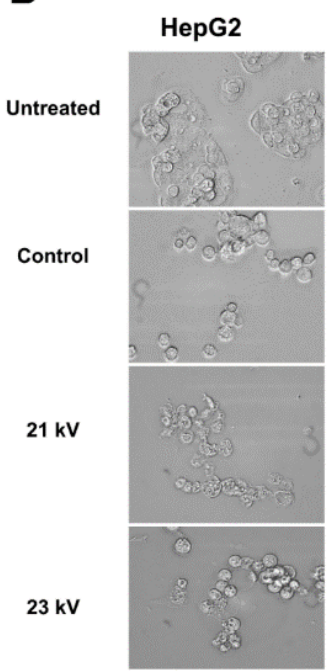

D

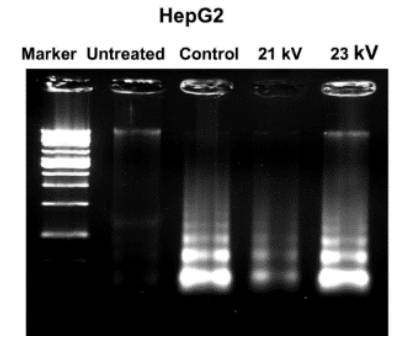

Fig. 6: Protein expression of MMP-2 and MMP-9 and gene expressions: A) Protein expression of MCF-7, B) Protein expression of HepG2, C) Gene expressions of MCF-7 and D) Gene expressions of HepG2. Data represented as mean $\pm \mathrm{SE}$ of three independent experiments. Different letters above columns indicate significant differences $(P<0.05)$

Untreated $=$ Cancer cells without any treatment; Control = MG microgreens from control seeds (no plasma-treated); $21 \mathrm{kV}=\mathrm{MG}$ microgreens from plasma-treated seeds at $21 \mathrm{kV} ; 23 \mathrm{kV}=\mathrm{MG}$ microgreens from plasma-treated seeds at $23 \mathrm{kV}$

MCF-7 (Fig. 6C) and HepG2 (Fig. 6D) after exposure to 50 $\mu \mathrm{g} / \mathrm{mL}$ microgreen extract for $24 \mathrm{~h}$ which were significantly higher than those of the untreated group. MG microgreen extracts from plasma-treated seeds caused more inducing effect to $M M P-9$ gene expressions than those from control seeds in both cancers, but no difference was found in other genes (Fig. 6C-D). The most potent effect was from MG microgreen extracts from plasma-treated seeds at $23 \mathrm{kV}$.

\section{Cancer cell morphology and DNA fragmentation}

Under phase-contrast microscopy, cell death and morphological changes in cancer cells were detected. The sizes of MG microgreen extract-treated MCF-7 and HepG2 cells appeared smaller than those untreated cells after $24 \mathrm{~h}$ (Fig. 7A-B). Both cancer cells shrank, and the membrane blebbed. The organelle condensation appeared as black spots inside the cancer cells and cells were broken into smaller cells.

Fig. 7: Cancer cell morphology and DNA fragmentation after 24 h exposure to MG microgreen extracts: A) MCF-7 morphology, B) HepG2 morphology, C) DNA fragmentation of MCF-7 and D) DNA fragmentation of HepG2

Untreated = Cancer cells without any treatment; Control = MG microgreens from control seeds (no plasma-treated); $21 \mathrm{kV}=\mathrm{MG}$ microgreens from plasma-treated seeds at $21 \mathrm{kV} ; 23 \mathrm{kV}=\mathrm{MG}$ microgreens from plasma-treated seeds at $23 \mathrm{kV}$

The results of DNA fragmentation showed that 100 $\mu \mathrm{g} / \mathrm{mL}$ of all $\mathrm{MG}$ microgreen extracts led to typical ladder pattern of internucleosomal DNA fragmentation from both MCF-7 (Fig. 7C) and HepG2 (Fig. 7D) on agarose gel when compared to the unbroken DNA from the untreated cells. In cancer cell death, MG microgreen extracts were able to cause apoptosis as observed by DNA fragmentation.

\section{Discussion}

The results from this work led to the acceptance of our hypothesis that cold plasma treatment on MG seeds was able to increase seed germination, ITC content, bioactive compounds and anticancer activity of MG microgreens when compared to those grown from the control seeds without plasma treatment.

Cold plasma treatment at $23 \mathrm{kV}$ resulted in the highest germination percentage possibly because $23 \mathrm{kV}$ was optimal to enrich the seed surface with oxygen-containing functional groups as in the previous report (Amnuaysin et al. 2018) 
and thus increased water absorption ability and loosening of the seeds (Müller et al. 2009) which may increase seed germination and growth (Jiayun et al. 2014). In addition, cold plasma treatment at 21 and $23 \mathrm{kV}$ on MG seeds was able to increase ITC content when compared to that of control MG. This increase may be the result of cold plasma ability to induce glucosinolate synthetic genes and thus ITC production. Previously, $10 \mathrm{~m} M \mathrm{CaCl}_{2}$ priming as abiotic stressor or elicitor was able to induce $B r S T 5 b$ (sulfotransferase 5b) and BrAOP2 (2-oxoglutaratedependent dioxygenase 2) gene expressions for increased glucosinolate biosynthesis in broccoli sprouts (Yang et al. 2016) and thus enhanced corresponding ITC products.

Hydroxyl $(\mathrm{OH})$ radical, singlet oxygen, Ar- and $\mathrm{N}^{2}$ excited-species generated during cold plasma treatment may induce reactive nitrogen species (RNS) and reactive oxygen species (ROS) generation along with UV radiation, shock wave, and photons (Matra 2018). These species may stimulate stress in MG seeds/microgreens leading to increased glucosinolate biosynthesis (subsequent hydrolysis to ITCs) or antioxidant enzymes or non-enzymatic antioxidants (Bußler et al. 2015; Zhang et al. 2017). ROS was found to stimulate stress-causing synthesis of 4hydroxyglucobrassicin and neoglucobrassicin glucosinolates (Torres-Contreras et al. 2018) and another previous report showed that light stimulated plant myrosinase that hydrolyzed glucosinolates to ITCs (Yamada et al. 2003). Similar to the previous reports of mature MG plants (Olivier et al. 1999; Arora et al. 2016), the two dominant ITCs found in MG microgreens in this study were AITC and 3-butenyl ITC.

Plasma-treated seeds at $23 \mathrm{kV}$ gave the highest values of TPC and TFC. Cold plasma treatment at $23 \mathrm{kV}$ on seeds may act as an abiotic stressor by generating RNS and ROS and thus induce TPC and TFC synthesis in MG microgreens. It is known that the phenylpropanoid pathway produces phenolic compounds in plants and can be stimulated by environmental stressors and elicitors (Kim et al. 2006; Giorgi et al. 2009; Yuan et al. 2010).

The cytotoxic effect results showed that the lowest $\mathrm{IC}_{50}$ value towards MCF-7 at $72 \mathrm{~h}$ was observed in $23 \mathrm{kV}$ $(32.44 \pm 1.64 \mu \mathrm{g} / \mathrm{mL})$. However, for HepG2, the lowest $\mathrm{IC}_{50}$ value at $72 \mathrm{~h}$ was found in control $(28.58 \pm 1.04 \mu \mathrm{g} / \mathrm{mL})$. The highest cytotoxic effect from $23 \mathrm{kV}$ may be due to the highest ITC, TPC and TFC contributing to the most potent anticancer effect towards MCF-7 at 72 h. For antiproliferative effect, $\mathrm{MG}$ extracts from $21 \mathrm{kV}$ treatment gave the lowest $\mathrm{IC}_{50}$ values towards MCF-7 (23.23 \pm 0.23 $\mu \mathrm{g} / \mathrm{mL})$ and HepG2 $(20.44 \pm 0.56 \mu \mathrm{g} / \mathrm{mL})$ followed by those from $23 \mathrm{kV}$ treatment $(31.28 \pm 1.05 \mu \mathrm{g} / \mathrm{mL}$ and 29.53 $\pm 1.22 \mu \mathrm{g} / \mathrm{mL}$, respectively). This suggested that the highest DPPH scavenging activity from MG microgreen extracts from $21 \mathrm{kV}$ treatment may have an important role in antiproliferation of both cancer cells. In addition, lower $\mathrm{IC}_{50}$ values of MG microgreen extracts from 21 and $23 \mathrm{kV}$ treatment were able to inhibit colony formation when compared to those used to induce cytotoxicity suggesting that MG microgreen extracts from 21 and $23 \mathrm{kV}$ treatment at low concentrations were more suitable for longer-term use in antiproliferation against MCF-7 and HepG2.

The most potent bioactive compound responsible for anticancer effect of MG microgreen extracts was assumed to be ITC. According to the previous reports, 3-butenyl ITC extract from Brassica juncea showed $\mathrm{IC}_{50}$ of $0.049 \mu \mathrm{L} / \mathrm{mL}$ against HepG2 and $0.666 \mu \mathrm{L} / \mathrm{mL}$ against $\mathrm{MCF}-7$ (Arora et al. 2016). When compared to our results of crude $\mathrm{MG}$ microgreen extract, the higher IC50 values of $19.11 \pm 0.35$ $\mu \mathrm{g} / \mathrm{mL}$ for HepG2 and $28.35 \pm 0.23 \mu \mathrm{g} / \mathrm{mL}$ for MCF-7 after $72 \mathrm{~h}$ exposure were found suggesting lower efficacy than those of the previous work. ITC and bioactive compounds may stimulate caspase-3 activity and thus induce apoptosis (Steelman et al. 2004). AITC was able to prohibit MCF-7 cell proliferation and reduce $\mathrm{Bcl}-2$ gene expression (Sayeed et al. 2018). AITC was found to activate caspase-8, -9 and -3 , deactivate anti-apoptotic protein $\mathrm{Bcl}-2$ and activate proapoptotic protein leading to apoptosis in MCF-7 (Bo et al. 2016) and induce DNA fragmentation (Murata et al. 2000). These results of the previous studies were in accordance with our results in that caspase-3 gene expression increased in MCF-7 and $\mathrm{Bcl}-2$ gene expression decreased in HepG2 upon MG microgreen treatments from control, $21 \mathrm{kV}$ and $23 \mathrm{kV}$ when compared with the untreated cells. In addition, 3-butenyl ITC from B. juncea L. Czern var. Pusa Jaikisan exhibited cytotoxicity on cervical cancer, liver cancer, and breast cancer with reduction in MMPs protein expression that contributed to antimigration of cancer cells (Gottlieb et al. 2003; Kim et al. 2011; Arora et al. 2016). This was also comparable to our finding in that MMP 2 and MMP 9 protein expressions significantly decreased in MCF-7 and HepG2 upon MG microgreen treatments from $21 \mathrm{kV}$ (with more pronounced effect) and $23 \mathrm{kV}$.

\section{Conclusion}

Overall MG microgreen extracts from cold plasma-treated seeds at $21 \mathrm{kV}$ was most effective regarding cytotoxicity against MCF-7 at $48 \mathrm{~h}$ and HepG2 at $24 \mathrm{~h}$ and $48 \mathrm{~h}$, antiproliferation and antimigration against both cancer cells. This is the first report to highlight the significant influence of cold-plasma treatment on $\mathrm{MG}$ seeds and food functionality of the corresponding $\mathrm{MG}$ microgreens including increased bioactive contents, DPPH antioxidant activity and anticancer properties. Cold plasma can be considered as an innovative and clean technology for food and agricultural applications especially microgreen industry starting from the seeds to developing functional foods with enhanced antioxidant and chemopreventive benefits.

\section{Acknowledgments}

This research was financially supported by Mahasarakham University (Fast Track 2020). The authors would like to 
thank Department of Biotechnology, Faculty of Technology, Mahasarakham University (MSU), Thailand and Central Laboratory at MSU for research facilities.

\section{Author Contributions}

VL designed, conducted the experiments, analyzed data and wrote the manuscript. WS and TK conducted the experiments. TK and KM contributed samples, materials, or data. BB and SD designed the experiments. All authors listed have read and approved the manuscript for publication.

\section{References}

Alrifai O, X Hao, MF Marcone, R Tsao (2019). Current review of the modulatory effects of LED lights on photosynthesis of secondary metabolites and future perspectives of microgreen vegetables. $J$ Agric Food Chem 67:6075-6090

Amnuaysin N, H Korakotchakorn, S Chittapun, N Poolyrat (2018). Seed germination and seedling growth of rice in response to atmospheric air dielectric-barrier discharge plasma. Songklanakarin J Sci Technol 40:819-823

Amron NA, N Konsue (2018). Antioxidant capacity and nitrosation inhibition of cruciferous vegetable extracts. Intl Food Res J 25:65-73

Arora R, R Kumar, J Mahajan, AP Vig, B Singh, B Singh, S Arora (2016). 3-Butenyl isothiocyanate: A hydrolytic product of glucosinolate as a potential cytotoxic agent against human cancer cell lines. J Food Sci Technol 53:3437-3445

Bo P, JC Lien, YY Chen, FS Yu, HF Lu, CS Yu, YC Chou, CC Yu, JG Chung (2016). Allyl isothiocyanate induces cell toxicity by multiple pathways in human breast cancer cells. Amer J Chin Med 44:415-437

Bradford MM (1976). A rapid and sensitive method for the quantitation of microgram quantities of protein utilizing the principle of protein-dye binding. Anal Biochem 72:248-254

Bray F, J Ferlay, I Soerjomataram, RL Siegel, LA Torre, A Jemal (2018). Global cancer statistics 2018: GLOBOCAN estimates of incidence and mortality worldwide for 36 cancers in 185 countries. CA Cancer J Clin 68:394-424

Bußler S, WB Herppich, S Neugart, M Schreiner, J Ehlbeck, S Rohn, O Schlüter (2015). Impact of cold atmospheric pressure plasma on physiology and flavonol glycoside profile of peas (Pisum sativum 'Salamanca'). Food Res Intl 76:132-141

Buranrat B, N Mairuae, A Konsue (2017). Cratoxy formosum leaf extract inhibits proliferation and migration of human breast cancer MCF-7 cells. Biomed Pharmacother 90:77-84

Buranrat B, L Senggunprai, A Prawan, V Kukongviriyapan (2016). Simvastatin and atorvastatin as inhibitors of proliferation and inducers of apoptosis in human cholangiocarcinoma cells. Life Sci 153:41-49

Burnett JP, G Lim, Y Li, RB Shah, R Lim, HJ Paholak, SP McDermott, L Sun, Y Tsume, S Bai, MS Wicha (2017). Sulforaphane enhances the anticancer activity of taxanes against triple negative breast cancer by killing cancer stem cells. Cancer Lett 394:52-64

Butscher D, HV Loon, A Waskow, PRV Rohr, M Schuppler (2016). Plasma inactivation of microorganisms on sprout seeds in a dielectric barrier discharge. Intl J Food Microbiol 238:222-232

Dobrin D, M Magureanu, NB Mandache, MD Ionita (2015). The effect of non-thermal plasma treatment on wheat germination and early growth. Innov Food Sci Emerg Technol 29:255-260

Fahey JW, AT Zalcmann, P Talalay (2001). The chemical diversity and distribution of glucosinolates and isothiocyanates among plants. Phytochemistry 56:237-285

Frazie MD, MJ Kim, KM Ku (2017). Health-promoting phytochemicals from 11 mustard cultivars at baby leaf and mature stages. Molecules 22; Article 1749
Geng F, L Tang, Y Li, L Yang, KS Choi, AL Kazim, Y Zhang (2011). Allyl isothiocyanate arrests cancer cells in mitosis, and mitotic arrest in turn leads to apoptosis via Bcl-2 protein phosphorylation. J Biol Chem 286:32259-32267

Giorgi A, M Mingozzi, M Madeo, G Speranza, M Cocucci (2009). Effect of nitrogen starvation on the phenolic metabolism and antioxidant properties of yarrow (Achillea collina Becker ex Rchb.). Food Chem 114:204-211

Gottlieb E, SM Armour, MH Harris, CB Thompson (2003). Mitochondrial membrane potential regulates matrix configuration and cytochrome $\mathrm{c}$ release during apoptosis. Cell Death Different 10:709-717

Halkier BA, J Gershenzon (2006). Biology and biochemistry of glucosinolates. Annu Rev Plant Biol 57:303-333

Ishida M, M Hara, N Fukino, T Kakizaki, Y Morimitsu (2014). Glucosinolate metabolism, functionality and breeding for the improvement of Brassicaceae vegetables. Breed Sci 64:48-59

Jiayun T, HE Rui, Z Xiaoli, ZH Ruoting, CH Weiwen, YA Size (2014). Effects of atmospheric pressure air plasma pretreatment on the seed germination and early growth of Andrographis paniculata. Plasma Sci Technol 16; Article 260

Kennedy DO, EL Wightman (2011). Herbal extracts and phytochemicals: Plant secondary metabolites and the enhancement of human brain function. Adv Nutr 2:32-50

Khanam UKS, S Oba, E Yanase, Y Murakami (2012). Phenolic acids, flavonoids and total antioxidant capacity of selected leafy vegetables. J Funct Foods 4:979-987

Kim HJ, F Chen, X Wang, JH Choi (2006). Effect of methyl jasmonate on phenolics, isothiocyanate, and metabolic enzymes in radish sprout (Raphanus sativus L.). J Agric Food Chem 54:7263-7269

Kim KY, SN Yu, SY Lee, SS Chun, YL Choi, YM Park, CS Song, B Chatterjee, SC Ahn (2011). Salinomycin-induced apoptosis of human prostate cancer cells due to accumulated reactive oxygen species and mitochondrial membrane depolarization. Biochem Biophy Res Commun 413:80-86

Kyriacou MC, Y Rouphael, FD Gioia, A Kyratzis, F Serio, M Renna, SD Pascale, P Santamaria (2016). Micro-scale vegetable production and the rise of microgreens. Trends Food Sci Technol 57:103-115

Luang-In V, S Deeseenthum, P Udomwong, W Saengha, M Gregori (2018). Formation of sulforaphane and iberin products from Thai cabbage fermented by myrosinase-positive bacteria. Molecules 23; Article 955

Luang-In V, A Narbad, C Nueno-Palop, R Mithen, M Bennett, JT Rossiter (2014). The metabolism of methylsulfinylalkyl- and methylthioalkylglucosinolates by a selection of human gut bacteria. Mol Nutr Food Res 58:875-883

Matra K(2018). Atmospheric non-thermal argon-oxygen plasma for sunflower seedling growth improvement. Jpn J Appl Phys 57; Article 1S

Muhammad AI, X Liao, PJ Cullen, D Liu, Q Xiang, J Wang, S Chen, X Ye, $T$ Ding (2018). Effects of non-thermal plasma technology on functional food components. Compr Rev Food Sci Food Saf 17:1379-1394

Müller K, A Linkies, RA Vreeburg, SC Fry, A Krieger-Liszkay, G Leubner-Metzger (2009). In vivo cell wall loosening by hydroxyl radicals during cress seed germination and elongation growth. Plant Physiol 150:1855-1865

Murata M, N Yamashita, S Inoue, S Kawanishi (2000). Mechanism of oxidative DNA damage induced by carcinogenic allyl isothiocyanate. Free Rad Biol Med 28:797-805

Olivier C, SF Vaughn, ES Mizubuti, R Loria (1999). Variation in allyl isothiocyanate production within Brassica species and correlation with fungicidal activity. J Chem Ecol 25:2687-2701

Pankaj SK, Z Wan, W Colonna, KM Keener (2017). Effect of high voltage atmospheric cold plasma on white grape juice quality. J Sci Food Agric 79:4016-4021

Park SY, GY Kim, SJ Bae, YH Yoo, YH Choi (2007). Induction of apoptosis by isothiocyanate sulforaphane in human cervical carcinoma HeLa and hepatocarcinoma HepG2 cells through activation of caspase-3. Oncol Rep 18:181-187

Pocasap P, N Weerapreeyakul, S Barusrux (2013). Cancer preventive effect of Thai rat-tailed radish (Raphanus sativus $\mathrm{L}$. var. caudatus Alef). $J$ Funct Foods 5:1372-1381 
Radošević K, VG Srček, MC Bubalo, SR Brnčić, K Takács, IR Redovniković (2017). Assessment of glucosinolates, antioxidative and antiproliferative activity of broccoli and collard extracts. J Food Compos Anal 61:59-66

Rueden CT, J Schindelin, MC Hiner, BE DeZonia, AE Walter, ET Arena, KW Eliceiri (2017). ImageJ2: ImageJ for the next generation of scientific image data. BMC Bioinform 18; Article 529

Sayeed MA, M Bracci, V Ciarapica, M Malavolta, M Provinciali, E Pieragostini, S Gaetani, F Monaco, G Lucarini, V Rapisarda, RD Primio (2018). Allyl isothiocyanate exhibits no anticancer activity in MDA-MB-231 breast cancer cells. Intl J Mol Sci 19:1-13

Shahidi F (2006). Functional Foods: Their role in health promotion and disease prevention. J Food Sci 69:146-149

Singh SV, K Singh (2012). Cancer chemoprevention with dietary isothiocyanates mature for clinical translational research. Carcinogenesis 33:1833-1842

Steelman LS, SCPohnert, JGShelton, RAFranklin, FEBertrand, JA McCubrey (2004). JAK/STAT, Raf/MEK/ERK, PI3K/Akt and BCR-ABL in cell cycle progression and leukemogenesis. Leukemia 18:189-218

Thimmulappa RK, KH Mai, S Srisuma, TW Kensler, M Yamamoto, S Biswal (2002). Identification of Nrf2-regulated genes induced by the chemopreventive agent sulforaphane by oligonucleotide microarray. Cancer Res 62:5196-5203

Tian M, X Xu, Y Liu, L Xie, S Pan (2016). Effect of Se treatment on glucosinolate metabolism and health-promoting compounds in the broccoli sprouts of three cultivars. Food Chem 190:374-380

Torres-Contreras AM, M González-Agüero, L Cisneros-Zevallos, DA Jacobo-Velázquez (2018). Role of reactive oxygen species and ethylene as signaling molecules for the wound-induced biosynthesis of glucosinolates in broccoli (Brassica oleracea L. 'Italica'). Acta Hortic 1194:909-913

Van Eylen D, MH Indrawati, A Van Loey (2006). Temperature and pressure stability of mustard seed (Sinapis alba L.) myrosinase. Food Chem 97:263-271

Wang LG, XM Liu, Y Fang, W Dai, FB Chiao, GM Puccio, J Feng, D Liu, JW Chiao (2008). De-repression of the p21 promoter in prostate cancer cells by an isothiocyanate via inhibition of HDACs and c-Myc. Intl J Oncol 33:375-380
Wei Y, Z Liu, Y Su, D Liu, X Ye (2011). Effect of salicylic acid treatment on postharvest quality, antioxidant activities, and free polyamines of asparagus. J Food Sci 76:126-132

Wu SJ, LT Ng, CC Lin (2005). Effects of antioxidants and caspase-3 inhibitor on the phenylethyl isothiocyanate-induced apoptotic signaling pathways in human PLC/PRF/5 cells. Eur J Pharmacol 518:96-106

Xiao D, V Vogel, SV Singh (2006). Benzyl isothiocyanate-induced apoptosis in human breast cancer cells is initiated by reactive oxygen species and regulated by Bax and Bak. Mol Cancer Ther 5:2931-2945

Yamada K, T Hasegawa, E Minami, N Shibuya, S Kosemura, S Yamamura, $\mathrm{K}$ Hasegawa (2003). Induction of myrosinase gene expression and myrosinase activity in radish hypocotyls by phototropic stimulation. J Plant Physiol 160:255-259

Yang R, Q Hui, Z Gu, Y Zhou, L Guo, C Shen, W Zhang (2016). Effects of $\mathrm{CaCl}_{2}$ on the metabolism of glucosinolates and the formation of isothiocyanates as well as the antioxidant. $J$ Funct Foods 24:156-163

Zhang DD, M Hannink (2003). Distinct cysteine residues in Keap1 are required for Keap1-dependent ubiquitination of $\mathrm{Nrf} 2$ and for stabilization of Nrf2 by chemopreventive agents and oxidative stress. Mol Cell Biol 23:8137-8151

Yuan G, X Wang, R Guo, Q Wang (2010). Effect of salt stress on phenolic compounds, glucosinolates, myrosinase and antioxidant activity in radish sprouts. Food Chem 121:1014-1019

Zhang JJ, JO Jo, RK Mongre, M Ghosh, AK Singh, SB Lee, YS Mok, P Hyuk, DK Jeong (2017). Growth-inducing effects of argon plasma on soybean sprouts via the regulation of demethylation levels of energy metabolism-related genes. Sci Rep 7; Article 41917

Zhang L, ZC Tu, T Yuan, H Wang, X Xie, ZF Fu (2016). Antioxidants and $\alpha$-glucosidase inhibitors from Ipomoea batatas leaves identified by bioassay-guided approach and structure-activity relationships. Food Chem 208:61-67

Zhang Y, L Tang (2007). Discovery and development of sulforaphane as a cancer chemopreventive phytochemical. Acta Pharmacol Sin 28:1343-1354 